\author{
Universidade de São Paulo \\ Instituto de Física
}

\title{
O Modelo de Cascata Intranuclear MCMC e Aplicações para o Mecanismo do Quase- Dêuteron e a Fotoprodução de Pions em Energias Intermediárias e Altas.
}

\section{Tulio Eduardo Rodrigues}

Tese de doutorado apresentada ao Instituto de Física da Universidade de São Paulo para a obtenção do título de Doutor em Ciências

Banca Examinadora:

Prof. Dr. João Dias de Toledo Arruda Neto (Orientador) - IFUSP

Prof. Dr. Fernando Silveira Navarra - IFUSP

Prof. Dr. Marcos Nogueira Martins - IFUSP

Prof. Dr. Diógenes Galetti - IFT, UNESP

Prof. Dr. Tobias Frederico - I TA 
“...I feel a responsibility as a scientist who knows the great value of a satisfactory philosophy of ignorance, and the progress made possible by such a philosophy, progress which is the fruit of freedom of thought. I feel a responsibility to proclaim the value of this freedom and to teach that doubt is not to be feared, but that it is to be welcomed as the possibility of a new potential for human beings. If you know that you are not sure, you have a chance to improve the situation. I want to demand this freedom for future generations." 
À minha esposa Cíntia e ao meu filho Mateus. 


\section{Agradecimentos}

A minha esposa Cíntia e ao meu filho Mateus pela inigualável paciência e compreensão nos últimos três anos, possibilitando a execução deste trabalho.

Ao Professor João Arruda por sua preciosa orientação e amizade.

Ao Dr. Joel Mesa por sua grande contribuição no desenvolvimento e aprimoramento do ferramentário apresentado nesta tese.

Aos doutorandos Cesar Garcia e Katherin Shtejer por sua participação ativa, possibilitando o desenvolvimento de um trabalho em equipe.

Aos Professores Sérgio Duarte e Odilon Tavares por sua contribuição nos momentos que pudemos interagir.

Ao Professor Dan Dale e ao Pos-doc Itaru Nakagawa pela calorosa hospitalidade em Newport News, motivando o estudo de mecanismos de fotoprodução de pions em altas energias.

À FAPESP pelo apoio financeiro.

Aos professores, bolsistas e funcionários do LAL. 


\section{Resumo}

O Presente trabalho propôs o estudo de reações fotonucleares e fotoprodução de pions em energias intermediárias e altas usando o modelo de cascata intranuclear MCMC para a fase rápida de reação e outro algoritmo de Monte Carlo para descrever o processo de decaimento do núcleo composto via evaporação de partículas e fissão nuclear. Dentre as principais inovações implementadas no MCMC, podemos citar: i) a inclusão detalhada do canal do quase-dêuteron no intervalo $20 \leq E_{\gamma} \leq 140 \mathrm{MeV}$; ii) o desenvolvimento inédito e rigoroso de um mecanismo de bloqueio de Pauli não-estocástico, avaliando as excitações partícula-buraco em tempo real na fase de pré-equilíbrio; iii) a incorporação de um critério energético de parada para a cascata; iv) a utilização de distribuições de momento apropriadas para núcleos leves (Modelo de Camadas), v) a inclusão de canais de fotoprodução do $\pi^{0}$ na região da $\Delta(1232)$ e em altas energias $4,0 \leq E_{\gamma} \leq 6,0 \mathrm{GeV}$ e ângulos frontais e, vi) a metodologia inédita para avaliar as interações de estado final de mésons e ressonâncias com o núcleo via cenário de espalhamentos múltiplos. O mecanismo do quase-dêuteron reproduz satisfatoriamente as seções de choque totais de fotoabsorção e as multiplicidades médias de nêutrons emitidos em núcleos pesados, interpretando qualitativamente as seções de choque para os canais de eletrodesintegração (e,xnyp) do

${ }^{232} \mathrm{Th}$. A contribuição de um possível processo de fotoabsorção por poucos corpos no ${ }^{232} \mathrm{Th}$ é analisada via canal de fotofissão. Os cálculos das distribuições angulares na fotoprodução incoerente do $\pi^{0}$ para o ${ }^{12} \mathrm{C} \mathrm{e}{ }^{208} \mathrm{~Pb}$ em energias intermediárias estão em ótimo acordo com dados experimentais obtidos no Microton de Mainz (MAMI). Os resultados para as seções de choque das distribuições angulares do $\pi^{0}$ em altas energias servirão como referência na Colaboração PrimEx no Jefferson Laboratory Facility, propiciando a separação da parte incoerente das demais contribuições nucleares e eletromagnéticas e auxiliando na determinação precisa da meia-vida do decaimento radiativo $\pi^{0} \rightarrow \gamma \gamma$. 


\begin{abstract}
Photonuclear reactions and pion photoproduction at intermediate and high energies have been studied using the multicollisional intranuclear cascade model (MCMC) for the rapid reaction step and another Monte Carlo algorithm to describe the de-excitation of the compound nucleus via particle evaporation and nuclear fission. The new features of the MCMC are: $i)$ the detailed inclusion of the quasideuteron channel in the range $20 \leq E_{\gamma} \leq 140$ $\mathrm{MeV}$; ii) the development of a rigorous and completely new non stochastic Pauli blocking mechanism, taking into account particle - hole excitations during the pre-equilibrium stage; iii) the incorporation of an energetic criterion to stop de cascade; iv) the employment of an appropriate momentum distribution for light nuclei (Shell Model); v) the inclusion of $\pi^{0}$ photoproduction channels in the $\Delta(1232)$ region and at high energies $4.0 \leq E_{\gamma} \leq 6.0 \mathrm{GeV}$ and forward angles, and vi) the new methodology to evaluate the pion-nucleus and $\Delta$ nucleus Final State Interactions via a multiple scattering scenario. The quasideuteron mechanism reproduces the total photoabsorption cross sections and neutron multiplicities in heavy nuclei, giving a qualitative interpretation for the cross sections of the electrodisintegration channels (e,xnyp) from ${ }^{232} \mathrm{Th}$. The contribution of a possible few body photoabsorption process in ${ }^{232} \mathrm{Th}$ is evaluated via fission channel. The calculations of the $\pi^{0}$ angular distributions for incoherent production at intermediate energies for ${ }^{12} \mathrm{C}$ and ${ }^{208} \mathrm{~Pb}$ are in excellent agreement with the experimental data of the Mainz Microton (MAMI). The results of the $\pi^{0}$ angular distributions at higher energies will be reference for the PrimEx Collaboration at the Jefferson Laboratory Facility, propitiating the separation of the incoherent part from the remaining nuclear and electromagnetic contributions and helping to perform a high precision measurement of the $\pi^{0} \rightarrow \gamma \gamma$ radiactive decay width.
\end{abstract}

